\title{
Factors for the Quality of the Brazilian Car Rental Service
}

\author{
Gessica Mina Kim Jesus $^{\# 1}$, Gladys Dorotea Cacsire Barriga ${ }^{\# 2}$ \\ ${ }^{1,2}$ Sao Paulo State University, Production Engineering Department, Bauru, Brazil
}

\begin{abstract}
The purpose of this study is to identify the main factors that influence the quality of the car rental service in Brazil, from the perspective of customers. It is the first time that the main factors for the quality of the car rental service have been investigated considering the perspective of Brazilian customers. We adopted a survey based on a questionnaire. The results were analyzed using the binary logistic regression model. The main factors for the quality were: the company offers local maps and tourist information along with the car (odds ratio $=1.56$ ); the company has cars adapted for people with special needs (odds ratio $=1.39$ ); the company supplies cars with a choice of steering (odds ratio $=1.568$ ); the company has employees that are well dressed and look good (odds ratio $=1.58$ ); the company makes all tools and documents available (odds ratio $=1.75$ ); and the company offers compensation if inconveniences arise for customers (odds ratio $=1.51$ ). This study shows how companies can direct their efforts to reduce complaints and improve the satisfaction and quality of the car rental service in Brazil.
\end{abstract}

Keywords - Customer satisfaction, quality management, Rentqual, Servqual.

\section{INTRODUCTION}

The service industry is the fastest-growing sector worldwide (Khorshidi et al., 2016). In developed countries, the service sector occupies a prominent position in the economy, represented by the participation of labor and wealth generation, whose main indicator is GDP (Correa, 2016). The car rental service sector, in turn, has been growing, due to its association with the tourism sector. Put simply, if the tourism sector grows, other services such as car rental, hotels, and restaurants also experience growth.

In Brazil, the car rental sector is strategic for the economy. In 2019, the sector had a net revenue of 19 billion reais with a fleet of 997416 cars, employing 75104 people in the sector (BACRC, 2020). However, the car rental services sector is a competitive market. The entry of multinational companies in the Brazilian market, coupled with an increase in consumer demand, has required companies to improve quality control to ensure greater customer satisfaction (Ekiz et al., 2009). In addition, for companies to remain competitive it is necessary to create positive experiences to satisfy customer needs (Berry et al., 2002).

One way to increase customer satisfaction is to increase the quality of the service offered (Berry et al., 2002). However, in order to have an effective tool to evaluate the quality of car rental services, it is necessary to know its quality dimensions. In a pioneering attempt to establish this set of dimensions, Cahill (1972) dealt with the evaluation of the quality of the car rental service from a technical point of view; that is, the conformity of vehicle operation, analyzing factors such as lights, tire pressures, tread depth, brake function, radio, windshield wipers, washers, heater, gas tank, and cleaning.

After the 2000s, other works were published to address the quality of this sector, such as the work of (New, 2003), who studied the impact of training people in operations management, and Asconavieta et al. (2011) who presented an evolutionary algorithm to assist in optimizing car rental schedules, and transportation systems in general.

More recently, a study by Zhang et al. (2014) in China suggested tangibility, reliability, response, security, and empathy as dimensions (originating from SERVQUAL) to assess the quality of the Chinese car rental sector. The authors, highlighted empathy as the main dimension pointed out by exploratory factor analysis (EFA). On the other hand, Ekiz et al. (2009) identified the principal dimensions of comfort, delivery, safety, ergonomics, and accessibility in Cyprus, as a result of the application of EFA as well.

This study aims to identify which dimensions are more important for customer satisfaction regarding the quality of the car rental service in Brazil, using a different method of literature research: regression logistics. Usually, EFA is used to identify factors/dimensions of research. However, regression methods can also be used for this purpose. In this case, binary logistic regression was chosen because the dependent variable has only two 
DOI: $\underline{10.51386 / 25815946 / i j s m s-v 4 i 4 p 121}$

Volume: 4 Issue: 4

July to August 2021

https://www.ijjsmsjournal.org

results (satisfied with the service and not satisfied), using the variables found in the literature and systematized in the framework of this research as predictors.

The paper is organized as follows: Section 1 provides an introduction to the theme; Section 2 presents a theoretical review of the quality of car rental services; Section 3 details the research method; Section 4 presents and discusses the results; and, finally, the conclusions are presented in Section 5.

\section{THEORETICAL BACKGROUND}

\section{Quality of service and the dimensions for the car rental sector}

In the service industry, quality of service is an important prerequisite for achieving customer satisfaction (Cronin \& Taylor, 1992). Pizam et al. (2016) highlight that customer satisfaction is essential for the survival of companies. Parasuraman et al. (1985) state that perceptions of service quality are influenced by customer satisfaction. Gil et al. (2008) corroborate this view by highlighting that customer satisfaction is a determining criterion for the real quality of products and services.

Lee and Cheng (2018) state that the quality of the service is something intangible, resulting in changes even after the service is delivered, and recommend customer satisfaction as an indicator for its assessment. Parasuraman et al. (1985) believe that the quality of service is the result of comparisons between expectations and perceptions of the current performance of a service. That is, the concept can be defined as the difference between the perceived service and the expected service.

Applied to the car rental sector, quality of service can be seen as the difference between expectations and perceptions of services provided based on the dimensions of quality. Seeking to identify the dimensions that influence the quality of service in the car rental sector, Cahill (1972) published an article that presented technical specifications for monitoring the quality of the car rental service sector, in which the quality vision came from satisfactory vehicle operation. Thus, the factors considered were of a technical and functional character, being: lights, tire pressures, tread depth, brake function, radio, windshield wipers, heater, gas tank, and cleaning. In the research by Ekiz et al. (2009) carried out in Cyprus, an instrument for measuring quality called RENTQUAL was built from 18 factors distributed over 5 dimensions: comfort, delivery, safety, ergonomics, and accessibility.

Another research conducted by Zhang et al. (2014) in China also sought to analyze the quality of the car rental sector in that country. However, the objective was to analyze the impact of the dimensions established in SERVQUAL on the factors of customer satisfaction and loyalty. As a result, they concluded that the car rental industry in China is a disorganized market, contributing to the low quality observed. In addition, the study concluded that the empathy dimension most influenced service quality, positively impacting customer satisfaction and loyalty. The two main studies regarding the dimensions of the quality of service specific to the car rental sector are Ekiz et al. (2009) and Zhang et al. (2014), as presented above. However, other studies have also suggested improvements to the quality of this service sector, and they have been considered in this literature review. These studies are presented in the following section.

\section{Other dimensions of quality of service in the car rental sector}

Similar to that presented by Zhang et al. (2014) with respect to company reputation, the research by Ahn \& Park (2016) showed that brand reputation had a significant impact on the evaluation of the extended services for users of car rental services. In addition, brand also influenced the final decision to purchase the service. Regarding the "accessibility" dimension proposed in the evaluation by Ekiz et al. (2009), and the "response" and "empathy" dimensions mentioned in the instrument by Zhang et al. (2014), Shahid et al. (2015) investigated the effect of the presence of live video support in a car rental e-commerce environment, analyzing the factors of trust, perceived friendship and perceived quality of service. The results showed that the presence of live video contributed to an increase in the perception of support in the search for information, in addition to improving the perception of quality and the feeling of confidence in the provision of the service.

For Miao et al. (2014), the car rental service sector has a role to play in the popularization of the electric car. Their research examined how consumers value electric car rental, and what they consider to be added value, by addressing three factors of analysis: customer participation, service quality, and customer value. Through exploratory factor analysis and confirmatory data analysis, they concluded that customer participation increases customer satisfaction, and that post-purchase intentions are increased as service quality improves.

A study by Tsai et al. (2010) in Taiwan analyzed the relationship between service innovation, regulatory assessment, quality of service, and customer satisfaction. The results showed that service innovation had a positive influence on both service quality and customer satisfaction. The normative evaluation also positively 
DOI: $\underline{10.51386 / 25815946 / \mathrm{ijsms}-\mathrm{v} 4 \mathrm{i} 4 \mathrm{p} 121}$

Volume: 4 Issue: 4

July to August 2021

https://www.ijsmsjournal.org

influenced the quality of service and customer satisfaction. Finally, the quality of the service had a positive influence on customer satisfaction.

In France, a study of more than 10,000 households found that families sharing car rentals have high incomes and live in the nuclei of large cities, particularly in Paris. Car rental proved to be an occasional practice, in which $58 \%$ of the people who share cars are male, while $55 \%$ of secondary users are female. In families with single people, only $15 \%$ share car rentals. For a minority, the practice of renting a car has become a sustained habit (Papon \& Hivert, 2008).

In order to help global companies provide services with consistent quality across different cultures, the article by New (2003) developed a multimedia system for training the frontline staff of the company Avis Europe. The case study illustrates how multimedia technologies are important in documenting operations, even identifying complex texts related to the "emotional work" of service operations.

Another major company in the car rental industry, Enterprise Rent a Car, was under pressure to improve its quality scores in the early 1990s when the company was experiencing dramatic growth. The solution given by the then CEO was to tie the advancement of field managers' careers to the level of customer satisfaction in their operations. To this end, the "Enterprise Service Quality" index was created, measured monthly through surveys with customers. Since then, the average score of "completely satisfied" customers have continued to grow, along with market share (Taylor, 2003).

\section{Framework for the factors of quality of service in the car rental sector}

From the junction of the works that have contributed directly and indirectly to the improvement of the quality of the car rental sector, a framework has been designed with the factors and their respective factors according to consulted references (see Table 1). The framework with the factors of car rental service quality, shown in Table 1 , was the basis for the preparation of a questionnaire and subsequent collection of survey data, as detailed in the following section.

TABLE 1

QUALITY FACTORS OF CAR RENTAL SERVICE FOUND IN THE LITERATURE

\begin{tabular}{|c|c|c|}
\hline Factor & Description of the Factor & References \\
\hline $\mathrm{x}_{1}$ & The cars have air-conditioning & Ekiz et al. (2009) \\
\hline $\mathrm{x}_{2}$ & The cars have comfortable seats & Ekiz et al. (2009) \\
\hline $\mathrm{x}_{3}$ & The interior of the cars is spacious & Ekiz et al. (2009) \\
\hline $\mathrm{x}_{4}$ & The company offers flexibility when delivering the car & Ekiz et al. (2009), Zhang et al. (2014) \\
\hline $\mathrm{x}_{5}$ & The company offers flexibility when returning the car & Ekiz et al. (2009), Zhang et al. (2014) \\
\hline $\mathrm{x}_{6}$ & $\begin{array}{l}\text { Employees communicate about the car's functions and } \\
\text { accessories }\end{array}$ & Ekiz et al. (2009), Zhang et al. (2014) \\
\hline $\mathrm{x}_{7}$ & $\begin{array}{l}\text { The company offers local maps and tourist information along } \\
\text { with the car }\end{array}$ & $\begin{array}{l}\text { Ekiz et al. (2009), Zhang et al. (2014), Cahill } \\
\text { (1972) }\end{array}$ \\
\hline $\mathrm{x}_{8}$ & The cars are always clean and look good & $\begin{array}{l}\text { Ekiz et al. (2009), Zhang et al. (2014), Cahill } \\
\text { (1972) }\end{array}$ \\
\hline $\mathrm{x}_{9}$ & The fuel is sufficient & $\begin{array}{l}\text { Ekiz et al. (2009), Zhang et al. (2014), Cahill } \\
\text { (1972) }\end{array}$ \\
\hline $\mathrm{x}_{10}$ & $\begin{array}{l}\text { The company performs a consistent assessment of the condition } \\
\text { of the car }\end{array}$ & $\begin{array}{l}\text { Ekiz et al. (2009), Zhang et al. (2014), Cahill } \\
\text { (1972) }\end{array}$ \\
\hline $\mathrm{x}_{11}$ & The cars have security systems & $\begin{array}{l}\text { Ekiz et al. (2009), Zhang et al. (2014), Cahill } \\
\text { (1972) }\end{array}$ \\
\hline $\mathrm{x}_{12}$ & The company provides insurance & $\begin{array}{l}\text { Ekiz et al. (2009), Zhang et al. (2014), Cahill } \\
\text { (1972) }\end{array}$ \\
\hline $\mathrm{x}_{13}$ & $\begin{array}{l}\text { The company has cars adapted for the disabled or people with } \\
\text { special needs }\end{array}$ & Ekiz et al. (2009), Zhang et al. (2014) \\
\hline $\mathrm{x}_{14}$ & $\begin{array}{l}\text { The company supplies cars with a choice of steering } \\
\text { (mechanical or hydraulic/electric) }\end{array}$ & Ekiz et al. (2009), Zhang et al. (2014) \\
\hline $\mathrm{x}_{15}$ & $\begin{array}{l}\text { The company supplies cars with a transmission option (manual } \\
\text { or automatic) }\end{array}$ & Ekiz et al. (2009), Zhang et al. (2014) \\
\hline $\mathrm{x}_{16}$ & The company location is easily accessible & $\begin{array}{l}\text { Ekiz et al. (2009), Zhang et al. (2014), Miao et } \\
\text { al. (2014), Shahid et al. (2015) }\end{array}$ \\
\hline $\mathrm{x}_{17}$ & $\begin{array}{l}\text { Company employees are available around the clock to respond } \\
\text { to requests }\end{array}$ & $\begin{array}{l}\text { Ekiz et al. (2009), Zhang et al. (2014), Miao et } \\
\text { al. (2014), Shahid et al. (2015) }\end{array}$ \\
\hline
\end{tabular}




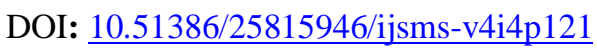

\begin{tabular}{|c|c|c|}
\hline $\mathrm{x}_{18}$ & $\begin{array}{l}\text { Employees respond quickly in the event of accidents or } \\
\text { technical problems }\end{array}$ & $\begin{array}{l}\text { Ekiz et al. (2009), Zhang et al. (2014), Miao et } \\
\text { al. (2014), Shahid et al. (2015) }\end{array}$ \\
\hline $\mathrm{x}_{19}$ & $\begin{array}{l}\text { The company provides convenient booking channels, such as } \\
\text { telephone, visits or online help }\end{array}$ & $\begin{array}{l}\text { Ekiz et al. (2009), Zhang et al. (2014), Miao et } \\
\text { al. (2014), Shahid et al. (2015) }\end{array}$ \\
\hline $\mathrm{x}_{20}$ & All information is available on the company website & $\begin{array}{l}\text { Ekiz et al. (2009), Zhang et al. (2014), Miao et } \\
\text { al. (2014), Shahid et al. (2015) }\end{array}$ \\
\hline $\mathrm{x}_{21}$ & The company offers video support to answer questions & $\begin{array}{l}\text { Ekiz et al. (2009), Zhang et al. (2014), Miao et } \\
\text { al. (2014), Shahid et al. (2015) }\end{array}$ \\
\hline $\mathrm{x}_{22}$ & The company has a clean and attractive environment & Zhang et al. (2014), Miao et al. (2014) \\
\hline $\mathrm{x}_{23}$ & The company's employees are well dressed and look good & Zhang et al. (2014), Miao et al. (2014) \\
\hline $\mathrm{x}_{24}$ & The company supplies new cars (up to 50000 km driven) & Zhang et al. (2014), Miao et al. (2014) \\
\hline $\mathrm{X}_{25}$ & The company complies with the service & Zhang et al. (2014), Miao et al. (2014) \\
\hline $\mathrm{x}_{26}$ & The price of the service is reasonable & Zhang et al. (2014), Miao et al. (2014) \\
\hline $\mathrm{X}_{27}$ & All tools and documents are available & Zhang et al. (2014), Miao et al. (2014) \\
\hline $\mathrm{x}_{28}$ & The registration of information takes place without fail & Zhang et al. (2014), Miao et al. (2014) \\
\hline $\mathrm{x}_{29}$ & $\begin{array}{l}\text { The company promotes innovative actions in the reservation } \\
\text { system via the Web }\end{array}$ & Zhang et al. (2014), Miao et al. (2014) \\
\hline $\mathrm{x}_{30}$ & The company supplies the car immediately upon request & $\begin{array}{l}\text { Zhang et al. (2014), Ahn \& Park (2016), New } \\
\text { (2003) }\end{array}$ \\
\hline $\mathrm{x}_{31}$ & $\begin{array}{l}\text { The company carries out innovative actions in the offer and } \\
\text { provision of the service }\end{array}$ & $\begin{array}{l}\text { Zhang et al. (2014), Ahn \& Park (2016), New } \\
\text { (2003) }\end{array}$ \\
\hline $\mathrm{x}_{32}$ & The company has a good reputation & $\begin{array}{l}\text { Zhang et al. (2014), Ahn \& Park (2016), New } \\
(2003)\end{array}$ \\
\hline $\mathrm{x}_{33}$ & Employees demonstrate know-how to explain the service & Zhang et al. (2014), New (2003) \\
\hline $\mathrm{x}_{34}$ & The lease is clear & Zhang et al. (2014), New (2003) \\
\hline $\mathrm{x}_{35}$ & $\begin{array}{l}\text { The company provides support to employees to improve the } \\
\text { service }\end{array}$ & Zhang et al. (2014), New (2003) \\
\hline $\mathrm{x}_{36}$ & The company handles complaints efficiently & Zhang et al. (2014), Miao et al. (2014) \\
\hline $\mathrm{x}_{37}$ & Employee communication is clear and effective & Zhang et al. (2014), Miao et al. (2014) \\
\hline $\mathrm{x}_{38}$ & The company shows interest in offering promotions & Zhang et al. (2014), Miao et al. (2014) \\
\hline $\mathrm{x}_{39}$ & $\begin{array}{l}\text { The company offers compensation if inconveniences arise for } \\
\text { customers }\end{array}$ & Zhang et al. (2014), Miao et al. (2014) \\
\hline $\mathrm{x}_{40}$ & There is company contact after the rental & Zhang et al. (2014), Miao et al. (2014) \\
\hline
\end{tabular}

\section{III.MATERIAL AND METHODS}

\section{Data collection}

In this work, the empirical research method with a quantitative approach and survey was used. The questionnaire, formulated based on the framework in Table 1, was sent by email or applied personally to the target population. The target population was made up of people who have rented a car at least once in the past two years in Brazil. Initially, a pilot test was carried out to improve the clarity of the questions in the questionnaire. Data collection was carried out during the year 2018 and returned a total of 195 valid responses. The questionnaire was designed in two sections: (a) to collect information about the users' socioeconomic characteristics (age, gender, occupation, income, education level, frequency, and reason for renting cars); (b) to select the factors relevant to the car rental quality of service (for example, car cleaning, seat comfort, company accessibility, ease of communication with employees, online booking systems, etc.). The complete list of factors is given in Table 1.

\section{Data analysis with logistic regression}

In the binary logistic regression model,40 independent factors found in the literature that shape the quality of the car rental service were considered, as shown in Table 1. The response variable yi represents customer satisfaction with the quality of the car rental service, a binary variable that can assume values of 0 or 1 . 
DOI: $\underline{10.51386 / 25815946 / \mathrm{ijsms}-\mathrm{v} 4 \mathrm{i} 4 \mathrm{p} 121}$

The logistic regression model obtained, applying the natural logarithm in the odds ratio (OR) function, given by (2).

Odds ration $=\exp \left[\left(\beta_{0}+\beta_{1} x_{1 i}+\beta_{2} x_{2 i}+\cdots+\beta_{40} x_{40 i}\right)\right]$

Where: $\mathrm{i}=1,2,3, \ldots, 195$ and $\beta 0, \beta 1, \beta 2, \ldots \beta 40$ are the parameters of the logistic regression model. The probability of the event of interest occurring, that is, the probability of the customer being satisfied with the quality of the car rental service, is given by (3).

$$
P\left(y_{i}=1 \mid x_{1 i}, \ldots, x_{40 i}\right)=\frac{1}{1+\exp \left[-\left(\beta_{0}+\beta_{1} x_{1 i}+\cdots+\beta_{40} x_{40 i}\right)\right]}
$$

Initially, we used the variant inflation factor test (VIF) and tolerance to examine the existence of multicollinearity between the 40 factors model. Thus, there is multicollinearity between factors if VIF > 10 or tolerance $<0.1$. However, no factor was excluded (see Table 2).

TABLE 2

TOLERANCE AND VIF VALUES OF FACTORS

\begin{tabular}{|c|c|c|c|c|c|}
\hline Factor & Tolerance & VIF & Factor & Tolerance & VIF \\
\hline & 0.371 & 2.695 & $x_{21}$ & 0.308 & 3.242 \\
\hline
\end{tabular}

\begin{tabular}{|c|c|c|c|c|c|}
\hline & & & & & \\
\hline $\mathrm{x}_{1}$ & 0.371 & 2.695 & $\mathrm{X}_{21}$ & 0.308 & 3.242 \\
\hline $\mathrm{X}_{2}$ & 0.485 & 2.060 & $\mathrm{X}_{22}$ & 0.383 & 2.612 \\
\hline $\mathrm{X}_{3}$ & 0.499 & 2.003 & $\mathrm{X}_{23}$ & 0.386 & 2.593 \\
\hline $\mathrm{X}_{4}$ & 0.488 & 2.049 & $\mathrm{X}_{24}$ & 0.394 & 2.539 \\
\hline $\mathrm{X}_{5}$ & 0.371 & 2.698 & $\mathrm{X}_{25}$ & 0.535 & 1.868 \\
\hline $\mathrm{x}_{6}$ & 0.345 & 2.898 & $\mathrm{X}_{26}$ & 0.384 & 2.607 \\
\hline $\mathrm{x}_{7}$ & 0.389 & 2.568 & $\mathrm{X}_{27}$ & 0.337 & 2.967 \\
\hline $\mathrm{X}_{8}$ & 0.421 & 2.377 & $\mathrm{X}_{28}$ & 0.312 & 3.210 \\
\hline $\mathrm{X}_{9}$ & 0.474 & 2.108 & $\mathrm{X}_{29}$ & 0.299 & 3.339 \\
\hline $\mathrm{X}_{10}$ & 0.540 & 1.853 & $\mathrm{X}_{30}$ & 0.455 & 2.198 \\
\hline $\mathrm{X}_{11}$ & 0.302 & 3.313 & $\mathrm{X}_{31}$ & 0.311 & 3.215 \\
\hline $\mathrm{X}_{12}$ & 0.284 & 3.523 & $\mathrm{X}_{32}$ & 0.441 & 2.268 \\
\hline $\mathrm{X}_{13}$ & 0.400 & 2.500 & $\mathrm{X}_{33}$ & 0.291 & 3.439 \\
\hline $\mathrm{X}_{14}$ & 0.324 & 3.086 & $\mathrm{X}_{34}$ & 0.238 & 4.204 \\
\hline $\mathrm{X}_{15}$ & 0.369 & 2.707 & $\mathrm{X}_{35}$ & 0.299 & 3.344 \\
\hline $\mathrm{X}_{16}$ & 0.332 & 3.008 & $\mathrm{X}_{36}$ & 0.334 & 2.993 \\
\hline $\mathrm{X}_{17}$ & 0.433 & 2.311 & $\mathrm{X}_{37}$ & 0.317 & 3.152 \\
\hline $\mathrm{X}_{18}$ & 0.364 & 2.748 & $\mathrm{X}_{38}$ & 0.328 & 3.047 \\
\hline $\mathrm{X}_{19}$ & 0.410 & 2.442 & $\mathrm{X}_{39}$ & 0.364 & 2.750 \\
\hline $\mathrm{X}_{20}$ & 0.390 & 2.563 & $\mathrm{X}_{40}$ & 0.447 & 2.238 \\
\hline
\end{tabular}

Source: Analysis results from SPSS

Binary logistic regression analysis was used to assess the associations between the 40 factors and customer satisfaction with quality when renting a car, with the odds ratio, 95\% confidence interval, and statistical significance value ( $p$-value $<0.05$ ). The results of the binary logistic regression are presented in factors for the quality of the car rental section.

\section{IV.RESULTS AND DISCUSSIONS}

Profile of the respondent 
DOI: $\underline{10.51386 / 25815946 / \mathrm{ijsms}-\mathrm{v} 4 \mathrm{i} 4 \mathrm{p} 121}$

In all, 195 valid responses were obtained. The respondent profile refers to the first part of the questionnaire that records information such as gender, age, education level, place of residence, area of activity, frequency of car rental in the last two years, and the reason for rental.

Table 3, which summarizes the main results found, shows that $58 \%$ of customers are male. The same percentage of male car rental users was found in France (58\%), in a survey profiling the French in the practice of car sharing (Papon \& Hivert, 2008). About 36\% of the sample is aged between 26 and 35 years old, and 63\% with higher education, agreeing with the results found by Ekiz et al. (2009) in their study carried out in Cyprus; the exception was age, which was in the range of 18 to 37 years. The results of the current research were different because, in Brazil, a minimum age of 21 years is required to rent a car.

The Brazilian states of Sao Paulo and Minas Gerais were the most representative, with $66 \%$ and $22 \%$ respondents, respectively. However, residents of the state of Goias, Rio de Janeiro, Bahia, and Paraná were also observed. Regarding the area of activity, many occupations were described by the respondents, from application drivers to people already retired. Table 3 shows the performance areas that most appeared in the results, with an emphasis on the Engineering area, encompassing Civil, Mechanical, and Production Engineering.

Table 3 shows that $66 \%$ of respondents made 1 to 3 car rentals in the last two years. Only $11 \%$ of customers have rented a car more than seven times in the past two years. These results are similar to those of Ekiz et al. (2009), who also found a low rental frequency among respondents. However, different results were found by Zhang et al. (2014) that point to a frequency of more than three times the rental for $36 \%$ of Chinese respondents.

Finally, Table 3 shows that tourism is the main reason for car rental in Brazil (75\%), followed by work or business reasons (21\%). In China, tourism was cited by $51 \%$ of the sample, and in Cyprus $54.1 \%$ of the sample. Other reasons cited in this research include car rental in the case of theft of or accidents with the renters' own vehicles, other accidents, and travel for health treatment.

TABLE 3

CHARACTERISTICS OF THE RESPONDENT'S PROFILE $(\mathrm{N}=195)$

\begin{tabular}{|c|c|c|}
\hline 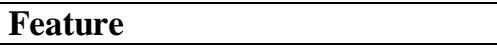 & Frequency & Frequency $(\%)$ \\
\hline \multicolumn{3}{|l|}{ Gender } \\
\hline Men & 113 & $58 \%$ \\
\hline Women & 82 & $42 \%$ \\
\hline \multicolumn{3}{|l|}{ Age } \\
\hline up to 25 years & 30 & $16 \%$ \\
\hline 26 to 35 years & 71 & $36 \%$ \\
\hline 36 to 45 years & 47 & $24 \%$ \\
\hline over 46 years & 47 & $24 \%$ \\
\hline \multicolumn{3}{|l|}{ Educational background } \\
\hline Non-scholarly & 0 & $0 \%$ \\
\hline Elementary School & 0 & $0 \%$ \\
\hline High School/Technical & 15 & $8 \%$ \\
\hline University education & 123 & $63 \%$ \\
\hline Postgraduate studies & 57 & $29 \%$ \\
\hline \multicolumn{3}{|l|}{ Place of residence } \\
\hline Sao Paulo & 128 & $66 \%$ \\
\hline Minas Gerais & 44 & $22 \%$ \\
\hline Goias & 17 & $8 \%$ \\
\hline Rio de Janeiro & 3 & $2 \%$ \\
\hline Others & 3 & $2 \%$ \\
\hline \multicolumn{3}{|l|}{ Occupation area } \\
\hline Administration & 12 & $6 \%$ \\
\hline Self-employed / Entrepreneur & 5 & $2 \%$ \\
\hline Trade & 6 & $3 \%$ \\
\hline Education & 15 & $8 \%$ \\
\hline Engineering & 25 & $13 \%$ \\
\hline Teacher & 7 & $4 \%$ \\
\hline Information Technology & 7 & $4 \%$ \\
\hline Sales & 8 & $4 \%$ \\
\hline
\end{tabular}


DOI: $\underline{10.51386 / 25815946 / \mathrm{ijsms}-\mathrm{v} 4 \mathrm{i} 4 \mathrm{p} 121}$

\begin{tabular}{|lll|} 
Others & 110 & $56 \%$ \\
\hline Car rental frequency (last two years) & & \\
1-3 times & 128 & $66 \%$ \\
4-6 times & 45 & $23 \%$ \\
7-10 times & 5 & $2 \%$ \\
more than ten times & 17 & $9 \%$ \\
\hline Reason for rental & & \\
Work or Business & 42 & $21 \%$ \\
Tourism & 147 & $76 \%$ \\
Visiting family or friends & 15 & $8 \%$ \\
Others & 5 & $3 \%$ \\
\hline
\end{tabular}

\section{Factors for the quality of the car rental service}

Initially, the quality of the fit of the logistic regression model was verified using the Hosmer-Lemeshow test that compares the observed and expected frequencies of events and non-events to assess whether the model fits the data well (Yu et al., 2017). The test value of Hosmer-Lemeshow must be greater than 0.05 and the overall hit rate greater than $60 \%$. In this research, the test value was 16.93 with a significance of 0.031 in the last step, with an overall accuracy of $80 \%$, satisfying the quality requirements for the fit of the model.

In addition, the final model had a $\log -2$ likelihood value of 160.39 , the R square Cox \& Snell was 0.218 , and the R square Nagelkerke was 0.332 . The estimates of the logistic regression coefficients, the standard error, the Wald test, the odds ratio, and the 95\% confidence interval for OR are shown in Table 4. The Wald test was used to indicate whether the factors have a significant effect on the probability of the customer being satisfied with the quality of the car rental service. That is, if the parameters associated with the model differ from zero to the $5 \%$ significance level.

TABLE 4

ESTIMATES OF THE COEFFICIENTS (B), STANDARD ERROR (SE), WALD TEST, ODDS RATIO (OR) AND CONFIDENCE INTERVAL (CI) 95\%

\begin{tabular}{|ccccccccc|}
\hline & & & & & & \multicolumn{3}{c|}{ CI 95\% for OR } \\
Factor & $\mathbf{B}$ & SE & Wald & df & Sig. & OR & Lower & Upper \\
\hline $\mathbf{X}_{6}$ & -0.432 & 0.191 & 5.131 & 1 & 0.024 & 0.649 & 0.447 & 0.943 \\
$\mathbf{x}_{\mathbf{7}}$ & $\mathbf{0 . 4 4 5}$ & $\mathbf{0 . 1 7 3}$ & $\mathbf{6 . 5 9 9}$ & $\mathbf{1}$ & $\mathbf{0 . 0 1}$ & $\mathbf{1 . 5 6 0}$ & $\mathbf{1 . 1 1 1}$ & $\mathbf{2 . 1 9}$ \\
$\mathrm{X}_{11}$ & -0.749 & 0.268 & 7.827 & 1 & 0.005 & 0.473 & 0.28 & 0.799 \\
$\mathbf{x}_{\mathbf{1 3}}$ & $\mathbf{0 . 3 2 7}$ & $\mathbf{0 . 1 6 2}$ & $\mathbf{4 . 0 6 1}$ & $\mathbf{1}$ & $\mathbf{0 . 0 4 4}$ & $\mathbf{1 . 3 8 7}$ & $\mathbf{1 . 0 0 9}$ & $\mathbf{1 . 9 0 6}$ \\
$\mathbf{x}_{\mathbf{1 4}}$ & $\mathbf{0 . 4 5 0}$ & $\mathbf{0 . 1 3}$ & $\mathbf{1 1 . 9 1}$ & $\mathbf{1}$ & $\mathbf{0 . 0 0 1}$ & $\mathbf{1 . 5 6 8}$ & $\mathbf{1 . 2 1 5}$ & $\mathbf{2 . 0 2 4}$ \\
$\mathbf{x}_{\mathbf{2 3}}$ & $\mathbf{0 . 4 5 7}$ & $\mathbf{0 . 1 8 6}$ & $\mathbf{6 . 0 5 2}$ & $\mathbf{1}$ & $\mathbf{0 . 0 1 4}$ & $\mathbf{1 . 5 8}$ & $\mathbf{1 . 0 9 7}$ & $\mathbf{2 . 2 7 4}$ \\
$\mathbf{x}_{\mathbf{2 7}}$ & $\mathbf{0 . 5 6 0}$ & $\mathbf{0 . 2 5 4}$ & $\mathbf{4 . 8 6}$ & $\mathbf{1}$ & $\mathbf{0 . 0 2 7}$ & $\mathbf{1 . 7 5 0}$ & $\mathbf{1 . 0 6 4}$ & $\mathbf{2 . 8 7 9}$ \\
$\mathrm{X}_{36}$ & -0.847 & 0.299 & 8.015 & 1 & 0.005 & 0.429 & 0.239 & 0.771 \\
$\mathrm{X}_{38}$ & -0.467 & 0.214 & 4.737 & 1 & 0.03 & 0.627 & 0.412 & 0.955 \\
$\mathbf{x}_{\mathbf{3 9}}$ & $\mathbf{0 . 4 1 1}$ & $\mathbf{0 . 2 4 4}$ & $\mathbf{2 . 8 5 3}$ & $\mathbf{1}$ & $\mathbf{0 . 0 9 1}$ & $\mathbf{1 . 5 0 9}$ & $\mathbf{0 . 9 3 6}$ & $\mathbf{2 . 4 3 2}$ \\
Constant & 1.167 & 1.906 & 0.375 & 1 & 0.54 & 3.212 & & \\
\hline
\end{tabular}

Note: Factors in bold are significant at 0.05 and have OR $>1.000$

To select the best logistic regression model, the backward stepwise method performed 31 steps by selecting the factors $\mathrm{x}_{6}, \mathrm{x}_{7}, \mathrm{x}_{11}, \mathrm{x}_{13}, \mathrm{x}_{14}, \mathrm{x}_{23}, \mathrm{x}_{27}, \mathrm{x}_{36}, \mathrm{x}_{38}$, and $\mathrm{x}_{39}$ for the model. However, factors with OR $>1$, which is associated with increased satisfaction with the quality of car rental services, are $\mathrm{x}_{7}, \mathrm{x}_{13}, \mathrm{x}_{14}, \mathrm{x}_{23}, \mathrm{x}_{27}$, and $\mathrm{x}_{39}$. Table 5 shows the descriptions of the significant factors with OR > 1, selected by the binary logistic regression.

TABLE 5

DESCRIPTION OF SIGNIFICANT FACTORS WITH ODDS RATIO $>1$

\begin{tabular}{|c|l|c|}
\hline Factor & \multicolumn{1}{|c|}{ Description of the Factor } & Odds Ratio (CI 95\%) \\
\hline $\mathrm{x}_{7}$ & The company offers local maps and tourist information along with the car & $1.56(1.11-2.19)$ \\
\hline $\mathrm{x}_{13}$ & The company has cars adapted for the disabled or people with special needs & $1.39(1.01-1.91)$ \\
\hline
\end{tabular}


DOI: $\underline{10.51386 / 25815946 / i j s m s-v 4 i 4 p 121}$

Volume: 4 Issue: 4

July to August 2021

https://www.ijsmsjournal.org

\begin{tabular}{|c|l|c|}
\hline $\mathrm{x}_{14}$ & $\begin{array}{l}\text { The company supplies cars with a choice of steering (mechanical or } \\
\text { hydraulic/electric) }\end{array}$ & $1.57(1.21-2.02)$ \\
\hline $\mathrm{x}_{23}$ & The company's employees are well dressed and look good & $1.58(1.10-2.27)$ \\
\hline $\mathrm{x}_{27}$ & All tools and documents are available & $1.75(1.06-2.88)$ \\
\hline $\mathrm{x}_{39}$ & The company offers compensation if inconveniences arise for customers & $1.51(0.94-2.43)$ \\
\hline
\end{tabular}

Table 5 shows that despite nine factors being significantly less than $\mathrm{s}$ for the model binary logistic regression, only six showed the value OR $>1$. This means that only $\mathrm{x}_{7}, \mathrm{x}_{13}, \mathrm{x}_{14}, \mathrm{x}_{23}, \mathrm{x}_{27}$, and $\mathrm{x}_{39}$ can increase satisfaction with the quality of car rental services. According to Table 5, the company offering local maps and tourist information together with the car increases the chance of customers being satisfied with the quality of the service provided by $56 \%$. This factor is consistent with the Brazilian reality, since the majority of respondents said they rented a car for tourism. This is also the case in the work of Ekiz et al. (2009) and Zhang et al. (2014) carried out in Cyprus and China, respectively.

Another relevant factor was companies providing cars adapted for the disabled or people with special needs. This shows that customers are becoming increasingly demanding about corporate social responsibility. Companies offers cars with steering options (mechanic or hydraulic/electric), was one of the factors relevant to the model of logistic regression. This factor, as with the previous (that is, providing cars adapted for people with special needs), was not relevant to respondents in the research of Ekiz et al. (2009), carried out in Cyprus.

In any case, Brazilian customers are interested in the variations of cars available, mainly with respect to the mechanical characteristics (steering options) and accessibility (cars adapted for people with special needs). These factors have led rental companies in Brazil to provide different types of cars to satisfy a wider range of customers. Therefore, investments in fleet renewal and improvement are factors to be considered by rental companies in Brazil.

In addition, the variety of options made available to customers, giving them autonomy in their choice when renting a car, follows a trend mentioned by Zhang et al. (2014), who emphasize that rental services tend to be customized based on customer needs. Thus, companies that do not adapt to this new scenario are likely to lose competitiveness. The company's capacity for innovation has a positive and significant influence on service quality (Sasono \& Novitasari, 2020).

Corroborating this view, identifying customer needs, New (2003) states that managers are motivated to invest in the quality of care through the training and qualification of frontline staff. In addition, employee training is important to understand the services and procedures inherent in the car rental process and to prepare employees for dealing with demanding customers (New, 2003).

The factor related to company employees being well-dressed and looking good is closely linked to tangible dimensions. In their study on the analysis of dimensions for the quality of car rental services offered in China, Zhang et al. (2014), state that this tangible dimension is considered one of the most important, along with reliability and responsiveness. It is important to invest in worker innovation and productivity, because they have a direct influence on the quality of service provided to the customer (Sasono \& Novitasari, 2020; Huynh et al., 2021).

The factor that refers to all tools and documents being available was the factor with the highest $\mathrm{OR}(\mathrm{OR}=$ 1.75 ; CI 95\% = 1.06-2.88); it was also the factor with the greatest chance of increasing the probability of customer satisfaction with the quality of rental services. For Johnston (1995), reliability is the main source of service quality and affects dissatisfaction more than satisfaction. Therefore, this dimension should be a qualifying criterion for the sector, without which the perception of service quality would be impaired (Slack et al., 2009).

Finally, the factor related to the company offering compensation in cases of inconvenience to customers was also the one that obtained an OR. This factor is related to employee service and empathy. According to Parasuraman et al. (1988), empathy concerns the care and individualized attention that a company offers its customers during service provision. Therefore, for companies to reach higher levels of quality and satisfaction, managers are motivated to invest in the quality of care through the training and qualification of their employees (New, 2003). In addition, employee training is important to understand the services and procedures inherent in the rental process and to prepare employees for dealing with potentially problematic customers (New, 2003).

Other identified factors 
DOI: $\underline{10.51386 / 25815946 / \mathrm{ijsms}-\mathrm{v} 4 \mathrm{i} 4 \mathrm{p} 121}$

In addition to the factors found in the literature, this research identified other factors associated with car rental in Brazil reported by respondents, such as: lack of payment method flexibility (since most only accept credit cards); the length of time taken to return security deposits charged to credit cards (because during such periods cards are blocked); undue collection for inspection failures (lack of standard inspection); tires in poor condition; expired car documents; delays in delivery of the vehicle; lack of internal cleanliness (cigarette smell); lack of attention to license plates (where car rotation policies are in place, such as in Sao Paulo); lack of tolerance over the time scheduled for delivery; lack of accessories (cell phone charger, tinted windows); unreliable booking (car unavailable or lower standard); location of the rental company difficult to access by public transport.

Therefore, the analysis of these factors together with the factors selected by the logistic regression can drive efforts to improve decision-making, seeking to reduce the number of complaints and, consequently, increase the satisfaction and the quality of service in the car rental sector from the perspective of the customer.

\section{Conclusions}

The car rental service in Brazil is a sector that has been growing in recent years. However, quantitative empirical studies related to this sector are scarce, being that the majority of published works are of a conceptual or qualitative nature. Studies on service quality are concentrated in sectors such as hotels, food, health, education, and banks. Thus, this work aimed to identify the factors of the quality of car rental services, which increase satisfaction from the perspective of consumers.

The results showed that men aged between 26 and 35 years old, with higher education are the most frequent renters. The main reason given for renting was tourism, with a rental frequency of 1 to 3 times a year. With respect to the logistic regression model, the provision of local maps and tourist information $(\mathrm{OR}=1.56$; CI 95\% $=1.11-2.19)$, the company provides cars adapted for the disabled $(\mathrm{OR}=1.39 ; \mathrm{CI} 95 \%=1.01-1.91)$, the company provides cars with a steering option $(\mathrm{OR}=1.57$; CI 95\% $=1.21-2.02)$, company employees are well dressed and look good $(\mathrm{OR}=1.58$; CI 95\% =1.09-2.27), all tools and documents are available $(\mathrm{OR}=1.75 ; \mathrm{CI}$ $95 \%=1.06-2.88)$ and the company offers compensation in the case of inconvenience $(\mathrm{OR}=1.51$; CI 95\% $=$ 0.94-2.43), were the main factors identified for the quality of car rental services.

In addition to these factors, respondents cited other factors that also affect the quality of the service, but were not present in the questionnaire. These factors are the company accepting various forms of payment (cash, card, checks, etc.), the fast return of deposits, the company paying attention to the validity periods of vehicle documents, paying attention to the license plate, respecting car rotation imposed by certain municipalities (especially the city of Sao Paulo), the condition of the tires, and supplying accessories that go with the car, such as cell phone chargers and tinted windows.

For future work, it is recommended that these factors be included factors in the logistic regression model to see whether they are significant predictors of satisfaction with the quality of car rental services. According to Zhang et al. (2014), the more customers are satisfied, the more loyal they will be to a given company. Loyal customers return to buy the product or hire the service repeatedly, recommending it to those they know, often by word of mouth, and thereby bringing new customers to a company.

However, this relationship between quality of service, loyalty, and communication by word of mouth was not addressed in this article, which merely identified the factors of quality service for rental. Therefore, it is recommended that future research also study the impact of factors of quality of service on the factors of loyalty and word of mouth communication. Another limitation of this study is that the questionnaire responses were based on the perception of quality after consuming the service, rather than considering the expectation before consuming the service (due to financial, monitoring, and time constraints). Therefore, the factors proposed in this study serve to encourage managers of the car rental industry to focus on relevant aspects, according to the perspective of customers, to evaluate the quality of the service provided.

\section{ACKNOWLEDGMENT}

The authors gratefully acknowledge the financial support of: (i) the Brazilian research funding agency CAPES, Coordination for the Improvement of Higher Education Personnel, Brazil (Grant 88887.605415/2021$00)$.

\section{REFERENCES}

[1] BACRC. Brazilian Association of Car Rental Companies. (2020). Sao Paulo: Ejota. 
DOI: $\underline{10.51386 / 25815946 / \mathrm{ijsms}-\mathrm{v} 4 \mathrm{i} 4 \mathrm{p} 121}$

Volume: 4 Issue: 4

July to August 2021

https://www.ijjsmsjournal.org

[2] Ahn, J. \& Park, J. (2016). Product to Service Extension: The Impact of Brand Equity on Upscaled Service. Human Factors and Ergonomics in Manufacturing \& Service Industries, 26(6), 728-739. https://doi.org/10.1002/hfm.20676

[3] Asconavieta, P. H., Goldbarg, M. C. \& Goldbarg, E. F. (2011). Evolutionary algorithm for the car renter salesman. In IEEE Congress of Evolutionary Computation, pp. 593-600.

[4] Berry, L. L., Carbone, L. P. \& Haeckel, S. H. (2002). Managing the total customer experience. MIT Sloan Management Review, 43(3), 85-89.

[5] Cahill, R. F. (1972). Rental Car Diagnostic Techniques (No. 720234). SAE Technical Paper.

[6] Correa, H. L. \& Caon, M. (2016). Service management. Sao Paulo: Atlas.

[7] Ekiz, E. H., Bavik, A. \& Arasli, H. (2009). RENTQUAL: A new measurement scale for car rental services. Tourism: An International Interdisciplinary Journal, 57(2), 135-153.

[8] Gil, I., Berenguer, G. \& Cervera, A. (2008). The roles of service encounters, service value, and job satisfaction in achieving customer satisfaction in business relationships. Industrial Marketing Management, 37(8), 921-939. https://doi.org/10.1016/j.indmarman.2007.06.008

[9] Cronin Jr, J. J. \& Taylor, S. A. (1992). Measuring service quality: a reexamination and extension. Journal of Marketing, 56(3), 55-68. https://doi.org/10.1177/002224299205600304

[10] Huynh, T. T., Nguyen, M. H. \& Vo, B. D. (2021). Service Quality Assessment at the Learning Resourse Center in Can Tho University, Vietnam. International Journal of Science and Management Studies, 4(4), 82-92.

[11] Johnston, R. (1995). The determinants of service quality: satisfiers and dissatisfiers. International Journal of Service Industry Management, 6(5), 53-71. https://doi.org/10.1108/09564239510101536

[12] Khorshidi, H. A., Nikfalazar, S. \& Gunawan, I. (2016). Statistical process control application on service quality using SERVQUAL and QFD with a case study in trains' services. The TQM Journal. 28, 195-215. https://doi.org/10.1108/TQM-02-2014-0026

[13] Lee, W. H. \& Cheng, C. C. (2018). Less is more: A new insight for measuring service quality of green hotels. International Journal of Hospitality Management, 68, 32-40. https://doi.org/10.1016/j.ijhm.2017.09.005

[14] Miao, R., Cao, J., Zhang, K., Chen, B., Jiang, Z. \& Wang, L. (2014). Value-added path of service-oriented manufacturing based on structural equation model: the case of electric car rental for instance. International Journal of Production Research, 52(18), 55025513. https://doi.org/10.1080/00207543.2014.916824

[15] New, S. (2003). Multimedia for international operations: a case study. International Journal of Operations \& Production Management. 23, 125-137. https://doi.org/10.1108/01443570310453299

[16] Papon, F. \& Hivert, L. (2008). Adulterous behaviour within the car-owner couple: some analyses from French panel data on car rental and car sharing within households. IATSS research, 32(2), 6-15. https://doi.org/10.1016/S0386-1112(14)60205-3

[17] Parasuraman, A., Zeithaml, V. A. \& Berry, L. (1988). SERVQUAL: A multiple-item scale for measuring consumer perceptions of service quality. 64(1), 12-40.

[18] Parasuraman, A., Zeithaml, V. A. \& Berry, L. L. (1985). A conceptual model of service quality and its implications for future research. Journal of Marketing, 49(4), 41-50. https://doi.org/10.1177/002224298504900403

[19] Pizam, A., Shapoval, V. \& Ellis, T. (2016). Customer satisfaction and its measurement in hospitality enterprises: a revisit and update. International Journal of Contemporary Hospitality Management, 28, 2-35. https://doi.org/10.1108/IJCHM-04-2015-0167

[20] Sasono, I. \& Novitasari, D. (2020). Enhancing Service Quality through Innovation Capabilities and Work Productivity. International Journal of Science and Management Studies, 3(5), 123-133.

[21] Shahid, S., Al Mahmud, A. \& Mubin, O. (2015, September). Video-conferencing in e-commerce website: effect on perceived service quality and trust. In IFIP Conference on Human-Computer Interaction (pp. 616-620). Springer, Cham. https://doi.org/10.1007/978-3319-22723-8_74

[22] Slack, N., Chambers, S. \& Johnston, R. (2009). Production management. Sao Paulo: Atlas.

[23] Taylor, A. (2003). Top box: Rediscovering customer satisfaction. Business Horizons, 46(5), 3-3.

[24] Tsai, M. T., Chuang, L. M., Chen, C. C. \& Chao, H. M. (2010). The research on the relationship among service innovation, normative evaluation, service quality and customer satisfaction-A case study of Taiwan car-rental carrier. Journal of Quality, 17(3), 207-227. 
DOI: $\underline{10.51386 / 25815946 / \mathrm{ijsms}-\mathrm{v} 4 \mathrm{i} 4 \mathrm{p} 121}$

[25] Yu, W., Xu, W. \& Zhu, L. (2017). A modified Hosmer-Lemeshow test for large data sets. Communications in Statistics-Theory and Methods, 46(23), 11813-11825. https://doi.org/10.1080/03610926.2017.1285922

[26] Zhang, M., Xie, Y., Huang, L., \& He, Z. (2014). Service quality evaluation of car rental industry in China. International Journal of Quality \& Reliability Management, 31, 82-102. https://doi.org/10.1 108/IJQRM-11-2012-0146 